\title{
道路鋼桁橋の走行荷重による動的影響評価
}

\section{SOME CONSIDERATIONS ON DYNAMIC EFFECT OF HIGHWAY STEEL GIRDER BRIDGES UNDER MOVING VEHICLES}

\author{
本田秀行* . 小堀為雄**.山田善 —*** \\ By Hideyuki HONDA, Tameo KOBORI and Yoshikazu YAMADA
}

\begin{abstract}
The dynamic effect of bridges under moving vehicles must be investigated to the decision of impact factor in the rational design of highway bridges. This dynamic effect is defined by the word of the dynamic factor in this study, and is distinguished between the dynamic factor and impact factor written by design specifications. The dynamic factor of single-span bridges under the equivalent vehicle load to design live load (L-20) is calculated. Numerical examples are presented to obtain the information of the dynamic factor of highway bridges consolidated the multi-span continuous bridges and the single-span bridges. Finally, the dynamic factor based on the response of deflection and bending moment of highway steel girder bridges is suggested by a function with the parameters of span number and span length.
\end{abstract}

\section{1. まえがき}

著者らは走行荷重に対する道路橋の動的影響として, 長大橋梁の一つである連続鋼析橋の動的性状について文 献 1),2)に報告した．本文はこれらの文献で触れなかっ た単純鋼析橋の動的係数を補足するとともに，単純鋼析 橋と連続鋼析橋亡を統合したより一般性のある道路鋼析 橋の動的係数に対する考察を行うものである.

本文では，まず，走行自動車荷重に対する道路橋の動 的影響を動的係数 (Dynamic factor) と呼び, 設計示方 書に採用されている衝撃係数之区別して考え，単純鋼析 橋の動的応答解析から，たわみ，あるいは曲げモーメン トに着目した動的係数に対して考究した. 次いで，単純 鋼枌橋で得た動的係数と著者らが前論文 ${ }^{11.2)}$ で提示した 多径間連続鋼析橋の動的係数とを統合した道路鋼析橋の 設計動的係数を考察した。 そして, 道路橋設計への適用 に対する一資料を得る目的から，本文で求めた設計動的 係数は, 最終的には設計示方書における衝撃係数を意味 し, 従来の研究で提案 ${ }^{3(4)}$ されている動的係数と異なっ

\footnotetext{
* 正会員 工博 金沢工業大学助教授 土木工学科 ( (921 石川県石川郡野々市町扇ケ丘7-1)

** 正会員 工博 金沢大学教授 工学部建設工学科

*** 正会員 工博 京都大学教授 工学部土木工学科
}

た形式で道路鋼桁橋の衝撃係数を示すことも試みた。

\section{2. 単純鋼桁橋の動的応答解析}

\section{（1）解 析 法}

本文は，単純析橋と連続析橋を統合した道路橋の動的 影響を考究することから，連続析橋について報告した前 論文 ${ }^{1,2)}$ 上同様な解析法を用いる。したがって，本節で は式中の記号や詳細な解析法の説明を省き, 本文に必要 な事項のみを以下に述べる.

a) 運動方程式

自動車-橋梁の振動系モデルを Fig. 1 に示す。この場 合の橋梁のたわみ $y(t, x)$, 曲げモーメント $M(t, x)$ は次 式のように表わされる.

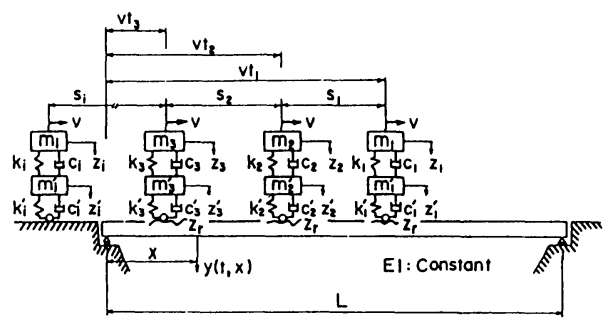

Fig.1 Vehicle-bridge vibration system. 


$$
\begin{aligned}
& y(t, x)=\sum_{n=1}^{\infty} q_{n}(t) \varphi_{n}(x) \\
& M(t, x)=\sum_{n=1}^{\infty} q_{n}(t) \varphi_{n}^{\prime \prime}(x)
\end{aligned}
$$

ここに， $\varphi_{n}(x)=\sin (n \pi x / L)$ である．数値計算として はNewmark の $\beta$ 法を用いて，たわみと曲げモーメント の忘答を求めた. なお, 計算の着目点 $x$ は支間中央点 の $x=L / 2$ とした.

b) 単純枌橋の動的係数

たわみ，あるいは曲げモーメントに着目した動的係数 $i_{y}, i_{M}$ をそれぞれの静的最大值に対する動振幅の最大值 の比に考え，次式で定義する.

$$
\begin{aligned}
& i_{y}=\frac{y_{d, \text { max }}-y_{s, \text { max }}}{y_{s, \text { max }}} . \\
& i_{M}=\frac{M_{d, \text { max }}-M_{s, \text { max }}}{M_{s, \text { max }}}
\end{aligned}
$$

c）橋梁の諸元と路面性状

Table 1 に対象とした橋梁の諸元を示す。この諸元は 建設省土木研究所の合成桁橋標準設計書より概算された 值である. 橋梁の固有振動数 $\omega_{n}$ を 4 次振動まで, 減衰 定数 $k_{n}=0.02$ を代表值として用いた。 また, 路面性状 を示す路面凹凸のパワースペクトル密度は, 著者らの実 態調查 ${ }^{51}$ で得られた平均的なスペクトルとして, $S_{r}$ $(\Omega)=0.011 \Omega^{-1.94}\left(\mathrm{~cm}^{2} /(\mathrm{c} / \mathrm{m})\right)$ を用いた。 このスペクトル を用いてモンテカルロ法から30個の路面凹凸のサンプル 波形を求めた2!

Table 1 Details of bridges considered.

\begin{tabular}{|c|c|c|c|c|c|c|}
\hline$L(\mathrm{~m})$ & 20 & 30 & 40 & 50 & 60 & 70 \\
\hline$W(\mathrm{kN})$ & 948.6 & 1520.8 & 2093.3 & 2665.6 & 3237.9 & 3810.2 \\
\hline $\begin{array}{l}E I \\
\left(M N \cdot \mathrm{m}^{2}\right)\end{array}$ & 12.712 & 24.343 & 47.844 & 82.712 & 128.929 & 157.094 \\
\hline
\end{tabular}

\section{（2）等価自動車荷重列の走行による応答解析}

設計活荷重（L-20）に相当する自動車荷重列の走行 による単純鋼桁橋のたわみに着目した動的係数 $i_{y}$ と支 間長 $L$ の関係を示したのが Fig. 2 である.なお, 自動車 の載荷方法は文献 2)に準じている. 図中の○は, 路面
凹凸の 30 個のサンプル波形に対して計算された動的係 数の平均値を, $\sigma$ はその標準偏差を示している. 動的係 数の平均値に標準偏差をプラス・マイナスした動的係数 の範囲を考えると，たとえば $L=40 \mathrm{~m}$ で計算した動的 係数の約 $76 \%$ はこの範囲に入る.この図から,その動 的係数の範囲は支間長の増大によって进減しているこ と，および支間長が $20 \mathrm{~m}$ 付近では自動車が単独走行す るために動的係数の標準偏差が最も大きくなっている が，支間長の増大によってその標準偏差は減少する傾向 にあることが認められる．前者の傾向は，自動車の載荷 台数の増加によって，静的たわみが大きくなっても，自 動車相互の振動の影響によって動的たわみの振幅がそれ ほど大きくならないことを示している．後者の傾向は, その動的たわみの振幅に及ぼす路面凹凸の影響が支間長 の増大と自動車の載荷台数の増加によって小さくなるこ とを示している。したがって，前述した両者から，自動 車荷重がその動的性状に及ぼす影響は支間長の増大に よって小さくなることが理解されよう.

ところで, Fig. 2 では 30 個の路面凹凸のサンプル波 形を用いて橋梁の応答計算をしたが，文献 2)で指摘し たように，本文でも路面凹凸の 30 個のサンプル波形に 対する動的係数の計算值を平均した結果を用いることに した，その平均値をみると，支間長によって変動してい るが，支間長の増大とともに莪減している，そこで，支 間長と動的係数の平均值との関係を近似式で表わすこと を検討した。その結果，たわみに着目した単純鋼析橋の 動的係数 $i_{y}=0.7(10 / L)$ の支間長 $L$ に対する派減関 数で表わすことができたので，それを図中に示した．

一方，設計活荷重（L-20）に相当する自動車荷重列 の走行による単純鋼桁橋の曲げモーメントに着目した動 的係数 $i_{M}$ と支間長 $L$ の関係を示したのが Fig. 3 であ る. 図中の記号はFig. 2 亡同様である. 動的係数の平均 值にその標準偏差をプラス・マイナスした動的係数の範 井，あるいは動的係数の標準偏差はFig. 2 と同様な傾向 を示している．そこで，動的係数の平均值に対する近似 式を検討した結果，曲げモーメントに着目した単純鋼桁

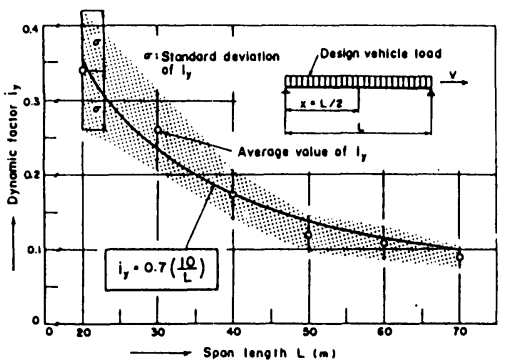

Fig. 2 Dynamic factor of deflection of single-span steel girder bridges.

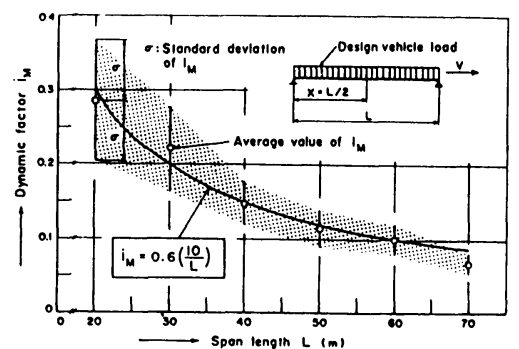

Fig. 3 Dynamic factor of bending moment of single-span steel girder bridges. 
橋の動的係数を $i_{M}=0.6(10 / L)$ で表わすことができたの で，それを図中に示した。

\section{3. 道路鋼桁橋の動的影響評価}

橋梁の設計示方書に採用されている衝撃係数は, 設計 活荷重による最大応力に対する動的影響として表わされ ている.このことから，衝撃係数を考究する場合には， 本来, 応力もしくは曲げモ一メントなどの断面力に着目 して検討を行う方が好ましい。しかし，実橋の振動実験 で設計衝撃係数を検証する場合，橋梁の構成部材のひず み量が小さいことなどから，たわみに着目して調査を行 うことも少なくない.したがって，道路橋の衝撃係数を 理論的・実験的に評価する場合には，曲げモーメントの ほかにたわみに着目することもあることから，その両者 に着目した衝撃係数を検討することも必要であろう.

そこで，本節では道路鋼析橋の動的影響評価として， たわみと曲げモーメントそれぞれに着目した動的係数の 両者を統一形式で表わすこと，および曲げモ一メントだ けに着目して表わすことを試みる。

\section{（1）たわみと曲げモーメントによる設計動的係数}

Fig. 2 に示した単純鋼析橋におけるたわみの動的係数 の近似式を新たに表わしたのが Fig.4である。なお，図 中の $n$ は径間数を示し, 単純析橋の場合は $n=1$ である. この図では，比較のために，おもな国の衝撃係数の現行 規定と従来の研究 ${ }^{3)}$ (4) で提案されている值をも示してい る. 単純鋼析橋で得た動的係数の近似式と著者らによる 曲線 D とを比較すると， 3 径間連続鋼析橋の方が約 $30 \%$ 小さい值となっている.

単純鋼析橋で得た動的係数の近似式と曲線 $\mathrm{A}$ とを比 較した場合，支間長が $27 \mathrm{~m}$ 以下での近似式は曲線 $\mathrm{A} よ$ りも大きい值となっており，わが国の現行規定は，この ような短支間橋梁に対して活荷重による動的影響を過小 評価しているものと思われる。一般に，短支間橋梁は固 有周期がきわめて短く，このような橋梁に動的影響を与 えるのは，短い周期をもち，載荷台数も 1 台か 2 台の自

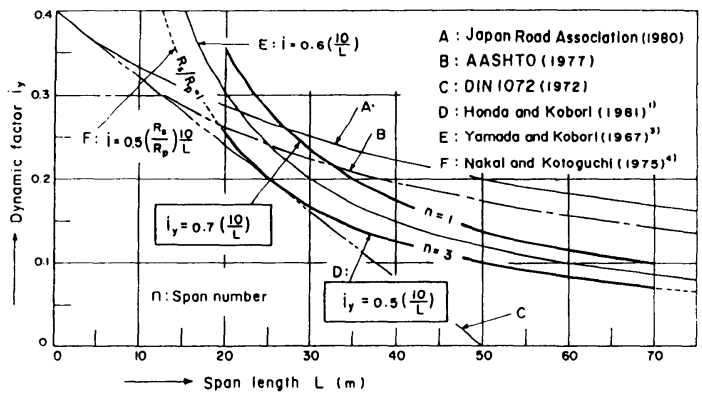

Fig. 4 Dynamic factor of deflection of highway steel girder bridges.
動車荷重であり，また路面の不整などに基づくものが多 い. したがって，短支間橋梁では，路面の平坦性が保証 されるならば衝撃係数を小さくしてもよいが，実際の路 面性状 ${ }^{51}$ 考えた場合，活荷重による橋梁の動的応答が 非常に敏感であることから，活荷重に対する動的影響を 多少多めに見積って設計することが必要であろう.また，

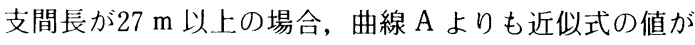
小さく，支間長の増大によってその差はさらに顕著とな る.このような支間長に対して，わが国の現行規定は橋 梁の動的影響を過大評価していると思われる．橋梁の支 間長が長くなれば，一般に死荷重応力に比べて活荷重応 力が小さくなることから, わずかの活荷重応力の増加は, 設計上，問題にならない。むしろ，衝撃係数の値をでき るだけ下げて，設計を合理化し，経済的な設計をするこ とが肝要であろう.

続いて, Fig. 3 に示した単純鋼析橋における曲げモ一 メントの動的係数の近似式を新たに表わしたのが Fig. 5 である。いま，単純鋼析橋で得た動的係数の近似式と著 者ら ${ }^{21}$ にる曲線とを比較すると，2，3，4，5 径間連続 鋼析橋の方がそれぞれ約 $21 ， 36 ， 44 ， 50 \%$ 単純鋼桁橋 の動的係数より小さい值を示している。これは, 文献 2) でも指摘したように，径間数の増加によって橋梁全体の 質量が橋梁の応答にそのまま効いていることによるもの と思われる.また，単純鋼桁橋で得た動的係数の近似式 と曲線 $\mathrm{A}$ とを比較すると, 支間長が $20 \mathrm{~m}$ 付近で現行規 定を若干超えているが。それ以上の支間長では曲線 $\mathrm{A}$ の方が大きい値となっている，この傾向は連続鋼析橋の 径間数の増加によってさらに顥著となることが認められ る.このことから，たわみの場合と同様，曲げモ一メン 卜に着目して動的係数を検討した場合でも，支間長が長 くて，また連続桁橋のように多くの径間数をもった道路 鋼析橋に対しでは，衝撃係数の值を下げて設計を合理化 することが必要であろう。

なお，Fig. 5 には示していないが，著者らは連続析橋 の中間支点部に対する動的影響を文献 2 )で検討した。

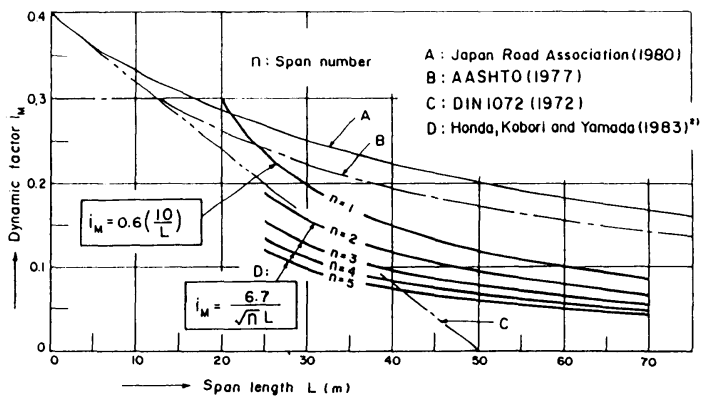

Fig. 5 Dynamic factor of bending moment of highway steel girder bridges. 
そして, $2 \sim 5$ 径間連続鋼析橋の径間数 $n$ と支間 $L$ を 考慮に入れて, 曲げモーメントに着目した中間支点部で の動的係数 $i_{M}=9.0 /(\sqrt{n} L)$ を提示した.

以上のような動的係数に対する考察から, 本文では, 道路鋼析橋の自動車荷重に対する動的影響として，たわ みと曲げモーメントに着目した設計動的係数 長 $L$ と径間数 $n$ を考慮して次式に示す.

$$
i=i_{1} \cdot i_{2} \cdot i_{3} \cdot i_{0}\left(\frac{10}{L}\right) \leq 0.4, \quad L \geq 20 \mathrm{~m}
$$

ここに， $i_{1}$ は道路鋼析橋の動的影響を評価する際にた わみ，あるいは曲げモーメントのいずれかに着目するか を表わす係数， $i_{2}$ は動的係数を算出する際の適用部が 径間部か中間支点部かを表わす係数， $i_{3}$ は橋梁形式が 単純鋼析橋か連続鋼析橋かを表わす係数，そして $i_{0}$ は 基準動的係数である.これら各係数のとる具体的な数值 を示したのが Table 2である.

Table 2 Design dynamic factor of deflection and moment of highway bridges $(L \geq 20 \mathrm{~m})$.

\begin{tabular}{|c|l|c|}
\hline \multicolumn{1}{|c|}{$i=i_{1} \cdot i_{2} \cdot i_{3} \cdot i_{0}\left(\frac{10}{L}\right)$} & 0.4 \\
\hline$i_{1}$ & Bending moment & 1.0 \\
\cline { 2 - 3 } & Deflection & 1.2 \\
\hline$i_{2}$ & Span & 1.0 \\
\cline { 2 - 3 } & Intermedlate support & 1.35 \\
\hline$i_{3}$ & Simple girder bridge & 0.9 \\
\cline { 2 - 3 } & $\begin{array}{l}\text { Continous girder bridge } \\
\text { (n: Span number) }\end{array}$ & $\begin{array}{c}1 / \sqrt{n} \\
2 \leq n \leq 5\end{array}$ \\
\hline$i_{0}$ & Standard dynamic foctor & 0.67 \\
\hline
\end{tabular}

なお，ここで式( 5 )に対して若干の考察を加える.

第 1 は, $i$ の最大值 0.4 についてである. Fig. 2,4でも 指摘したように, 載荷自動車が 1 台のような日常的な荷 重を受ける短支間橋梁では，活荷重に対する橋梁の動的 影響は非常に敏感である。このような短支間橋梁に対す る設計動的係数の最大値としては, Fig. 2,3に示した支 間長が $20 \mathrm{~m}$ における動的係数の平均值にその標準偏差 を加えた値を最大値に考え, 取扱いの簡単な数値として 0.4 を採用した。

第 2 は，たわみに着目して動的係数を求める場合，連 続桁橋における中間支点上のたわみが零となるため, 中 間支点部での動的影響が評価できなく, 動的係数の取扱 いに問題が残る点である. しかし，その評価は困難であ ることから，式( 5 )では連続鋼析橋の中間支点部におけ る動的影響を曲げモーメントに着目して求めた動的係数 の結果 ${ }^{2}$ に準拠した.

\section{（2）曲げモーメントによる設計動的係数}

曲げモーメントに着目した道路鋼析橋の設計動的係数 $i$ を, 式 ( 5 ) と同様な形式で次式に示す.

$$
i=i_{1} \cdot i_{2} \cdot i_{0}\left(\frac{10}{L}\right) \leq 0.4, \quad L \geq 20 \mathrm{~m} \cdots
$$

ここに， $i_{1}$ は動的係数を算出する際の適用部が径間部 か中間支点部かを表わす係数， $i_{2}$ は橋梁形式が単純鋼 析橋か連続鋼析橋かを表わす係数， $i_{0}$ は基準動的係数 である. Table 3 にこれら各係数の数値を示す.

Table 3 Design dynamic factor of moment of highway bridges $(L \geq 20 \mathrm{~m})$.

\begin{tabular}{|c|l|c|}
\hline & \multicolumn{3}{|c|}{$i=i_{1} \cdot i_{2} \cdot i_{0}\left(\frac{10}{L}\right) \leq 0.4$} \\
\hline$i_{1}$ & Spon & 1.0 \\
\cline { 2 - 3 } & Intermedlate support & 1.35 \\
\hline$i_{2}$ & Simple girder brldge & 0.9 \\
\cline { 2 - 3 } & $\begin{array}{c}\text { Continous girder bridge } \\
\text { ( } n: \text { Span number ) }\end{array}$ & $\begin{array}{c}1 / \sqrt{n}, \\
2 \leq n \leq 5\end{array}$ \\
\hline$i_{0}$ & Standard dynamic foctor & 0.67 \\
\hline
\end{tabular}

\section{4. あとがき}

本文で示した設計動的係数は，現行示方書における衝 撃係数の算出法に比べると多少複雑な形式で表わされて いる. しかし, 単純鋼析橋と多径間連続鋼析橋を統合し たより一般性のある道路鋼杕橋の動的影響を一つの聥減 関数で評価でき，その際たわみ，あるいは曲げモーメン 卜に着目したいずれの動的係数も算出できることは現行 の衝撃係数よりも合理的で, また有用であると思われる.

\section{参 考 文 献}

1）本田・小堀：走行自動車による 3 径間連続妳橋の動的応 答之衝撃係数, 土木学会論文報告集, No. 313, pp. 13～22, 1981 年 9 月.

2）本田・小堀・山田：多径間連続析橋の動的応答之衝係 数に関する考察, 土木学会論文報告集, No. 331, pp. 65 $\sim 73,1983$ 年 3 月.

3）山田・小堀：活荷重に対する道路橋の動的応答一衝擊係 数一に関する研究, 土木学会論文集, No. 148, pp. $40 \sim 50$, 1967 年12月.

4) Nakai, H. and Kotoguchi, H. : Dynamic response of horizontally curved girder bridges under random traffic flows, Proc. of JSCE, No. 244, pp. $117 \sim 128$, December, 1975.

5）本田・城戸・暒川・小堀：道路橋の路面凹凸パワースペ クトル密度に関する調查, 土木学会論文報告集, No. 315, pp. $149 \sim 155,1981$ 年 11 月.

(1984. 1. 13 • 受付) 